\title{
Upland Nesting Prairie Shorebirds: Use of Managed Wetland Basins and Accuracy of Breeding Surveys
}

\section{Utilisation de terres humides aménagées par les oiseaux de rivage des prairies nichant dans les hautes terres et précision des dénombrements d'individus nicheurs}

\author{
Cheri L. Gratto-Trevor $^{1}$
}

\begin{abstract}
Wetlands in southern Alberta are often managed to benefit waterfowl and cattle production. Effects on other species usually are not examined. I determined the effect of managed wetlands on uplandnesting shorebirds in southern Alberta by comparing numbers of breeding willets (Catoptrophorus semipalmatus), marbled godwits (Limosa fedoa), and long-billed curlews (Numenius americanus) among areas of managed wetlands, natural wetland basins, and no wetland basins from 1995 to 2000. Surveys were carried out at 21 sites three times each year. Nine to ten of these areas (each $2 \mathrm{~km}^{2}$ ) were searched for nests annually from 1998-2000. Numbers of willets and marbled godwits and their nests were always highest in areas with managed wetlands, probably because almost all natural wetland basins were dry in this region in most years. Densities of willets seen during pre-incubation surveys averaged $2.3 \mathrm{birds} / \mathrm{km}^{2}$ in areas of managed wetlands, 0.4 in areas of natural wetland basins, and 0.1 in areas with no wetland basins. Nest densities of willets (one search each season) averaged $1.5,0.9$, and $0.3 \mathrm{nests} / \mathrm{km}^{2}$ in areas of managed, natural, and no wetland basins, respectively. Similarly, pre-incubation surveys averaged 1.6, 0.6, and 0.2 godwits $/ \mathrm{km}^{2}$ in areas of managed, natural, and no wetland basins, and 1.2, 0.3 , and 0.1 godwit nests $/ \mathrm{km}^{2}$. For long-billed curlews, pre-incubation surveys averaged $0.1,0.2$, and $0.1 \mathrm{birds} / \mathrm{km}^{2}$, and $0,0.2$, and 0 nests $/ \mathrm{km}^{2}$. Nest success was similar in areas with and without managed wetlands. Shallow managed wetlands in this region appear beneficial to willets and marbled godwits, but not necessarily to long-billed curlews. Only $8 \%$ of marked willets and godwits with nests in the area were seen or heard during surveys, compared with $29 \%$ of pre-laying individuals and $42 \%$ of birds with broods. This suggests that a low and variable percentage of these birds is counted during breeding bird surveys, likely limiting their ability to adequately monitor populations of these species.
\end{abstract}

RÉSUMÉ. Dans le sud de l'Alberta, des terres humides sont souvent aménagées de façon à favoriser la production de sauvagine et de bétail. Habituellement, on n'étudie pas l'incidence de cet aménagement sur les autres espèces. De 1995 à 2000, j'ai déterminé les effets des terres humides aménagées sur les oiseaux de rivage qui nichent dans les hautes terres dans le sud de l'Alberta en comparant le nombre de Chevaliers semipalmés (Catoptrophorus semipalmatus), de Barges marbrées (Limosa fedoa) et de Courlis à long bec (Numenius americanus) qui nichaient dans des secteurs de terres humides aménagées, des bassins de terres humides naturels et des secteurs sans terres humides. Des dénombrements ont été effectués dans 21 sites, trois fois par année. Dans neuf ou dix de ces secteurs ( $2 \mathrm{~km} 2$ chacun), on a effectué une recherche annuelle des nids de 1998 à 2000. Le nombre de Chevaliers semipalmés, de Barges marbrées et de nids de ces espèces était toujours plus élevé dans les secteurs de terres humides aménagées, probablement parce que, la plupart de ces années, presque tous les bassins de terres humides naturels étaient asséchés dans cette

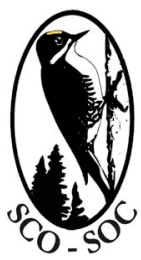

Sponsored by the Society of Canadian Ornithologists and Bird Studies Canada

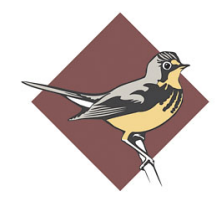


région. Chez le Chevalier semipalmé, pendant les dénombrements effectués avant l'incubation, les densités se situaient en moyenne à 2,3 individus $/ \mathrm{km} 2$ dans les secteurs de terres humides aménagées, à 0,4 dans les bassins de terres humides naturels et à 0,1 dans les secteurs sans bassins de terres humides. Le nombre moyen de nids (une recherche par saison) était de 1,5, de 0,9 et de $0,3 \mathrm{nid} / \mathrm{km} 2$ respectivement dans chacun de ces secteurs. De même, d'après les dénombrements précédant l'incubation, il y avait en moyenne 1,6, 0,6 et 0,2 Barge marbrée $/ \mathrm{km} 2$ dans les secteurs de terres humides aménagées, les bassins de terres humides naturels et les secteurs sans bassins de terres humides. Le nombre de nids de Barge marbrée était respectivement de 1,2,0,3 et $0,1 / \mathrm{km} 2$. Dans le cas du Courlis à long bec, les relevés précédant l'incubation ont permis de repérer en moyenne $0,1,0,2$ et 0,1 individu/ $\mathrm{km} 2$, ainsi que $0,0,2$ et $0 \mathrm{nid} / \mathrm{km} 2$. Le succès de la nidification était semblable dans les secteurs de terres humides aménagées et ceux où il n'y en avait pas. La présence de terres humides aménagées peu profondes dans cette région semble bénéfique pour le Chevalier semipalmé et la Barge marbrée, mais pas nécessairement pour le Courlis à long bec. Seulement $8 \%$ des oiseaux marqués (Chevaliers semipalmés et Barges marbrées) qui occupaient un nid dans la région ont été vus ou entendus pendant les dénombrements, comparativement à $29 \%$ des individus présents avant la ponte et $42 \%$ des oiseaux accompagnés de leur nichée. Ces résultats donnent à penser que le pourcentage des oiseaux de ces espèces dénombrés pendant les dénombrements d'individus nicheurs est faible et variable, ce qui limiterait l'efficacité de ceux-ci pour le suivi de ces espèces.

Key Words: Alberta; Catoptrophorus semipalmatus; climate change; conservation; Limosa fedoa; longbilled curlew; managed wetlands; marbled godwit; Numenius americanus; shorebird abundance; survey accuracy; wetland; willet

\section{INTRODUCTION}

Populations of many shorebird species are declining (Howe et al. 1989, Morrison et al. 1994, GrattoTrevor et al. 1998, Morrison et al. 2001). Outside of the arctic, the greatest number of North American shorebird species breed on the prairies (GrattoTrevor et al. 2001), which is of concern because grassland cultivation and wetland loss in the Canadian and the United States prairies (Dahl 1990, Environment Canada 1991) has resulted in significant range reductions of most prairie-nesting shorebirds (Howe 1982a; Page and Gill 1994), including upland nesting species such as long-billed curlews, Numenius americanus; western willets, Catoptrophorus semipalmatus inornatus; and marbled godwits, Limosa fedoa. Under most climate change scenarios, temperatures, and thus drought events, are expected to increase in this region (Herrington et al. 1997, Barrow and Yu 2005). This will further reduce numbers of the seasonal and semi-permanent wetlands primarily used by shorebirds (Kantrud and Stewart 1984, Diamond and Brace 1991, Sorenson et al. 1998, Clark et al. 2002). Many shallow wetlands in southern Alberta are managed for the benefit of cattle and waterfowl production by filling them with water in the spring and fall. During dry years in this region, these managed wetlands constitute most of the wetlands with water in the spring and summer. Although studies have clearly demonstrated the benefits of managed wetlands to waterfowl (e.g., Anderson and Glover 1967, Ruwaldt et al. 1979, Fairburn and Dinsmore 2001), as well as migrant shorebirds and those nesting at the edges of wetlands (e.g. Delphey and Dinsmore 1993, Weber and Haig 1996, Twedt et al. 1998, Colwell and Taft 2000), effects on upland nesting shorebirds are not known. Upland nesting prairie shorebirds normally nest several hundred meters to several kilometers from water in this region (Gratto-Trevor 2000, Lowther et al. 2001). They may not be as affected by changes in local water conditions as are species nesting at wetland edges. If they do nest in managed upland basins, they may have higher nest predation rates than those in unmanaged areas, if more predators are attracted to managed areas because of consistently high densities of nesting waterfowl there. Therefore, it is important to know if these shorebirds are as productive, and nest as abundantly, in areas with managed wetlands as in areas with natural wetland basins.

My first objective is to determine the abundance and productivity of upland breeding shorebirds in southern Alberta, comparing areas of managed, natural, and no wetland basins under natural weather conditions over 6 years. My second objective is to 
examine the accuracy of survey techniques, using nest searches and marked birds. The most common upland nesting shorebirds in this region are western willets and marbled godwits. Long-billed curlews are listed as a species of "special concern" by the Committee on the Status of Endangered Wildlife in Canada (Saunders 2002), and nest at much lower densities.

\section{STUDY AREA}

All study sites were within $100 \mathrm{~km}$ of Brooks, in Newell and Vulcan counties of southeastern Alberta, approximately $160 \mathrm{~km}$ east of Calgary (Fig. 1 , Table 1). Considerable amounts of native mixedgrass prairie still exist in this region, as much of this semi-arid habitat is used for cattle grazing. Oil and gas development is common. Breeding densities of marbled godwits and western willets are among the highest of anywhere in their range (Gratto-Trevor 2000, Lowther et al. 2001). In this area, six wetland complexes are managed by Ducks Unlimited Canada for cattle and waterfowl production. These are normally filled in spring and fall with irrigation water brought from the Bow River by canals. Survey sites with managed wetland basins were in the following areas: Kitsim, Kininvie South, Antelope Creek, Medicine Wheel, and Circle E. Kitsim consists of a series of more than 50 wetlands, ranging from about $16-120$ ha in size, connected by small canals in the early 1980s. At Kininvie South, wetlands in the study area were 6-30 ha. Canals were completed in 1976, but have had improved water supplies since 1984. Antelope Creek study area wetlands were 4-10 ha, with management structures completed by 1992 . Medicine Wheel wetlands were 4-42 ha. This site was first filled with water in the fall of 1994 and spring of 1995. Circle E wetlands were 10-70 ha. This area was first filled with water in 1997, after which it was considered a managed wetland in this study. Before 1997, it was considered a natural wetland area. Natural wetland basin areas have similar densities of wetland basins as managed areas and are used for cattle grazing, but are not connected by canals or managed for waterfowl production. Areas defined here as having no wetland basins $(<10 \%$ of the area as wetland basins) are not considered suitable for future wetland management, but are used for cattle grazing.

All study sites except Antelope Creek (owned by the Province of Alberta and leased to the Alberta
Fish and Game Association), Circle E (provincial Crown land managed by a grazing association), and Medicine Wheel (mostly provincial Crown land managed by a grazing association) are owned by the Eastern Irrigation District, Brooks, Alberta, Canada.

\section{STUDY SPECIES}

Long-billed curlews, marbled godwits, and western willets breed only in North America, primarily in prairie habitat (Gratto-Trevor 2000, Lowther et al. 2001, Dugger and Dugger 2002). Long-billed curlews arrive on the breeding grounds in early April; willets and godwits in late April and early May (Salt and Salt 1976, Higgins et al. 1979). Pairs are primarily formed or reunite on the breeding grounds. Nest initiation starts in early to mid May, slightly earlier for curlews. All are monogamous, with bi-parental incubation. Clutch size, as with most North American shorebirds, is almost always four. The incubation period is estimated at $23-25 \mathrm{~d}$ from laying of the fourth egg to hatch. Adults actively defend nests and broods against predators. Young are precocial, and leave the nest site almost immediately after hatch with their parents. They take close to a month to fledge (Sordahl 1979, Allen 1980, Howe 1982b, Redmond and Jenni 1986).

\section{METHODS}

\section{Surveys}

Because of the distribution of managed, natural, and no wetland basins, and access to different pastures, study sites were not randomly distributed across the landscape (Fig. 1). This did not affect results because averaging numbers of birds observed at clumped sites (thus reducing site numbers to five managed, three natural, and two no basin areas) resulted in very similar statistical findings as use of each site individually (e.g., wetland type differences were still highly significant).

I chose survey routes from aerial photographs, with prior knowledge of whether sites had managed, natural, or no wetland basins, but no knowledge of shorebird abundance. Survey routes at sites with managed or natural wetland basins were predetermined on the aerial photographs to run near as many wetland basins as possible. Once a survey 
Fig. 1. Map of study area in southern Alberta, with survey sites listed as being in areas of managed, natural, or no wetland basins. Numbers in parentheses after location represent the number of $5 \mathrm{~km}$ long routes in that area (and see Table 1). Asterisks after site names show survey sites that were nest-searched between 1998 and 2000 ( 1 asterisk = one 2-km ${ }^{2}$ area of survey route was searched; 2 asterisks $=$ one $2-\mathrm{km}^{2}$ area of each of two survey routes were searched). Dark lines and splotches represent rivers and lakes.

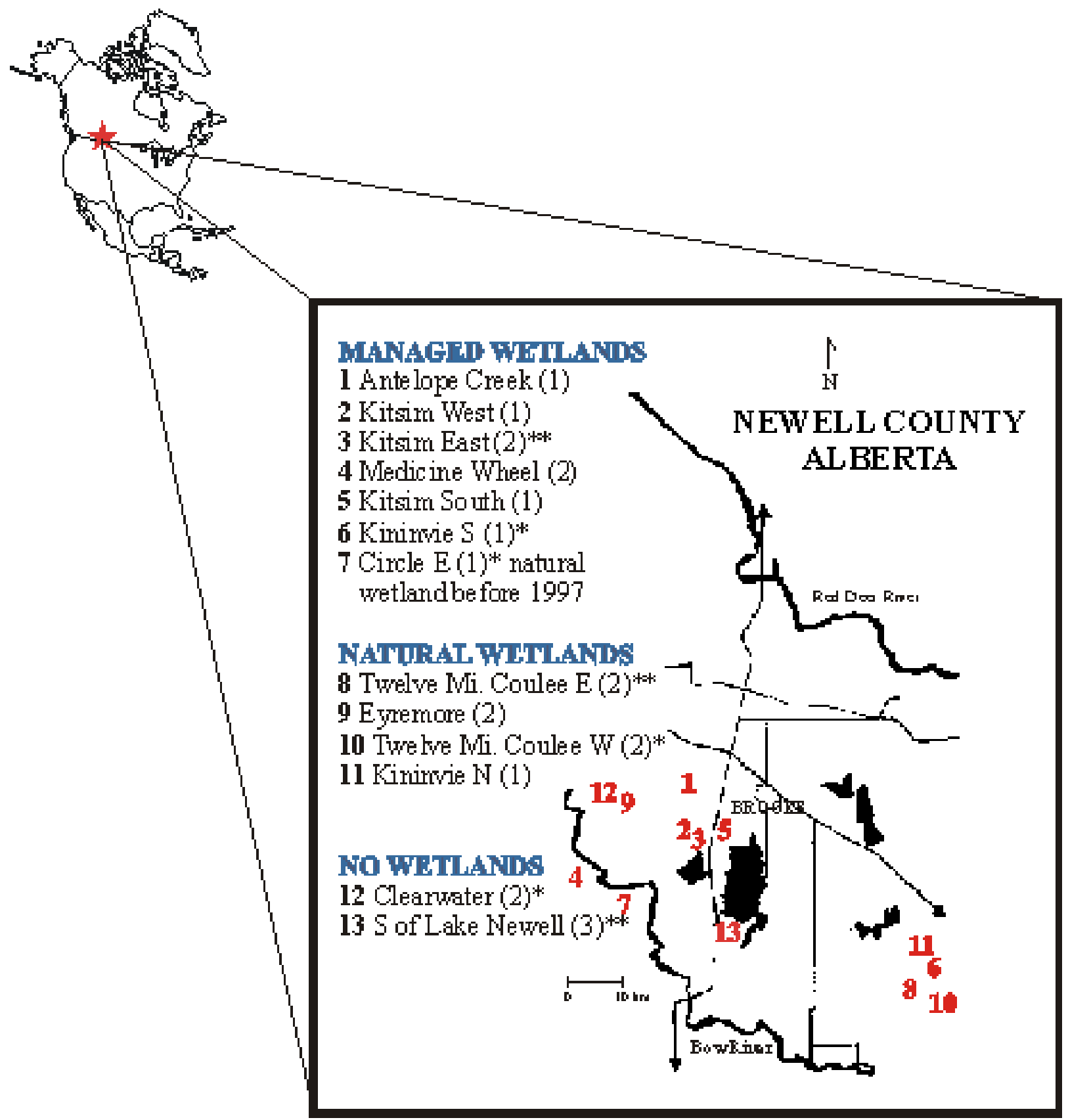


Table 1. Descriptive summary of survey sites from 1995 to 2000 in southern Alberta, including the percentage of the survey route area covered in water during the first survey each year.

\begin{tabular}{|c|c|c|c|c|c|c|c|c|c|}
\hline \multirow[b]{2}{*}{ Study site } & \multirow[b]{2}{*}{ Pasture } & \multirow[b]{2}{*}{$\begin{array}{l}\text { Wetland } \\
\text { basins }\end{array}$} & \multirow[b]{2}{*}{$\begin{array}{l}\text { Water ma- } \\
\text { nagement }\end{array}$} & \multicolumn{6}{|c|}{$\begin{array}{c}\text { Percentage of water } \\
\text { (of } 5 \mathrm{~km} \text { x } 0.5 \mathrm{~km} \text { survey route) }\end{array}$} \\
\hline & & & & 1995 & 1996 & 1997 & 1998 & 1999 & 2000 \\
\hline West Kitsim & native & managed & all years & 10 & 10 & 12 & 10 & 10 & 10 \\
\hline Kininvie 1 & native & managed & all years & 10 & 16 & 16 & 12 & 12 & 12 \\
\hline Antelope Creek & native & managed & all years & 8 & 8 & 8 & 7 & 7 & 7 \\
\hline E Kitsim 1 & native & managed & all years & 28 & 28 & 29 & 15 & 15 & 15 \\
\hline E Kitsim 2 & native & managed & all years & 16 & 16 & 16 & 12 & 12 & 12 \\
\hline Medicine Wheel 1 & native & managed & all years & 12 & 12 & 15 & 10 & 10 & 10 \\
\hline Medicine Wheel 2 & native & managed & all years & 21 & 21 & 22 & 20 & 20 & 20 \\
\hline South Kitsim & native & managed & all years & - & 29 & 30 & 12 & 12 & 12 \\
\hline Circle E & native & nat/man & 1997 on & 1 & 1 & 6 & 6 & 6 & 6 \\
\hline Kininvie 2 & native & natural & none & - & 8 & 12 & 1 & 1 & 1 \\
\hline 12 Mi Coulee E1 & native & natural & none & 0 & 1 & 1 & 0 & 0 & 0 \\
\hline 12 Mi Coulee E2 & native & natural & none & 0 & 1 & 2 & 0 & 0 & 0 \\
\hline Eyremore 1 & planted & natural & none & 3 & 2 & 6 & 3 & 3 & 3 \\
\hline Eyremore 2 & planted & natural & none & 3 & 2 & 5 & 1 & 1 & 1 \\
\hline 12 Mi Coulee W1 & native & natural & none & - & 5 & 8 & 1 & 1 & 1 \\
\hline 12 Mi Coulee W2 & native & natural & none & - & 5 & 2 & 0 & 0 & 0 \\
\hline S Newell 1 & native & none & none & 0 & 0 & 1 & 0 & 0 & 0 \\
\hline S Newell 2 & native & none & none & 0 & 0 & 0 & 0 & 0 & 0 \\
\hline S Newell 3 & native & none & none & - & 0 & 0 & 0 & 0 & 0 \\
\hline Clearwater 1 & native & none & none & 0 & 1 & 7 & 2 & 2 & 2 \\
\hline Clearwater 2 & native & none & none & 2 & 1 & 1 & 2 & 2 & 2 \\
\hline
\end{tabular}

was initiated (in 1995 or 1996), my assistant and I carried it out in all subsequent survey periods and years. Each survey route was $5 \mathrm{~km}$ in length.

I adapted methods from those of Ryan et al. (1984) and Ryan and Renken (1987). Each survey route was slowly travelled by all-terrain vehicle (ATV), stopping at least every $300 \mathrm{~m}$, scanning areas within $250 \mathrm{~m}$ of the route on all sides for shorebirds using $9 \times 36$ binoculars. In this generally flat terrain, these large upland nesting shorebirds were easily visible at $250 \mathrm{~m}$. Location and behavior of all shorebirds, as well as extent of wetlands was noted. One assistant and I carried out the surveys in all years, 
three times per season. In 1995, areas were surveyed during incubation (16-30 May), and early and late brood (mid-June; late June to early July) periods. Because few birds were seen during the incubation period, from 1996 to 2000 my assistant and I carried out surveys during the pre-incubation period (6-13 May), as well as twice during the brood care period. Birds were only considered to be in the survey if they landed or flushed from an area within $250 \mathrm{~m}$ of the survey route line. Groups of more than five birds (flocks) were eliminated from the analyses, as I considered these non-breeders. These were found only in managed wetlands, primarily during prebreeding.

Twenty-one sites were surveyed each year from 1996 to 2000. Nine were in areas of managed wetlands (Circle E was an area of natural wetland basins before 1997), seven in areas of natural wetland basins, and five in areas with no wetland basins (Fig. 1, Table 1). In 1995, my assistant and I surveyed only 16 of these sites, including seven in areas of managed wetlands, five in areas of natural wetland basins, and four in "no basin" areas (Fig. 1 ). The percentage of water in each survey route (Table 1) was determined by the percentage of the $5 \times 0.5 \mathrm{~km}$ survey route area covered in water during the first survey each year. I considered sites "wet" if over 5\% of the survey route area was covered in water, and "dry," otherwise. Except in the very wet spring of 1997, this split the sites into managed vs. unmanaged wetland areas.

\section{Survey Area Nest Searches}

My assistants and I searched $80 \%(4 \mathrm{~km} \times 0.5 \mathrm{~km})$ of the total area of each of the same nine survey routes (four managed, two natural, three "no basin") for shorebird nests by nest-drag technique $(30 \mathrm{~m}$ cable-chain or chain slowly dragged between two ATVs; Higgins et al. 1977, Klett et al. 1986) once each year from 1998 to 2000. In 1998 and 1999, a third natural wetland basin survey site was similarly searched. Because a much larger region was searched at Kitsim (an intensive study area searched twice a year from 1995-2000, where many shorebirds were captured on nests and marked), I drew an area $0.5 \mathrm{~km}$ wide $(250 \mathrm{~m}$ on each side of the survey line) around the first $4 \mathrm{~km}$ of East Kitsim route 1 as well as East Kitsim route 2. I counted all nests found in the first nest search that fell within the boundaries of these $0.5 \times 4 \mathrm{~km}$ areas for the purposes of this analysis.
All willet, godwit, and curlew nests were marked, and checked periodically (normally once weekly) for success or failure. I considered a nest successful if at least one chick hatched. Data for willets, godwits, and curlews were combined to increase sample size as there were no nest success differences among species. To determine incubation stage, eggs were floated in water (Hays and LeCroy 1971). Fates were determined for all nests, based on presence of chicks and condition of egg cup (C. L. Gratto-Trevor unpubl. data). I calculated both apparent (percentage of successful nests of all nests found) and Mayfield (1961, 1975; Klett et al. 1986) nest success rates. Because sample sizes were small, catastrophic events such as flooding or hail did not affect nest success, and sampling was inadequate to calculate state-specific survival rates, use of the Mayfield index was deemed more appropriate than other methods such as Mayfield logistic regression, Cox Proportional Hazards Regression, Logistic Exposure Model, the Stanley Method, Program Mark, and Kaplan-Meier (Manolis et al. 2000, Hazler 2004, Jehle et al. 2004, Nur et al. 2004, Shaffer 2004). Exposure days were calculated from the date the nest was found to the estimated hatch date (if it hatched), or if the nest was lost, to the midpoint of the date the nest was last seen with eggs and without eggs (40\% if the period between nest checks was $>6 \mathrm{~d}$ ). For each Mayfield nest success rate, $95 \%$ confidence limits were calculated (Johnson 1979).

\section{Survey Accuracy-Percentage of Marked Individuals Observed}

In the intensive study area at Kitsim, the site was searched for nests twice yearly from 1995 to 2000 . Nests found were marked with pin flags. Once the last egg was laid in a clutch, and full incubation was underway, I captured adult willets and marbled godwits on nests with mist nets (placed over the nest) or passive walk-in nest traps constructed of chicken-wire (Gratto-Trevor 2004). Adults were individually color banded. I also marked willet adults on their white wing bars and/or rump with yellow or pink dyes for easier recognition in flight. No nests were deserted as a result of nest searches or capturing adults on nest.

During surveys at Kitsim from 1995 to 1998, I checked all willets and godwits observed for bands. By comparing the number of banded birds potentially in the survey route at the time of the 
survey (i.e., how many marked birds were known to have nests or had been seen recently with broods within $250 \mathrm{~m}$ of the survey route line) with how many of these banded birds were actually seen during the survey, I obtained an estimate of survey accuracy for different periods of the breeding cycle. Data from 1995 to 1998 were combined to increase sample size in each category, as were species and surveys, as there were no differences among years and between species. Behavior of individual birds also provides insight into the accuracy of surveys. Therefore, during capture attempts in 1995, I collected data on flushing distance of the incubating bird and presence or absence of its mate.

\section{Comparative Wetland Conditions}

Spring wetland conditions in Prairie Canada are assessed through Pond Counts carried out in conjunction with the annual Waterfowl Breeding Population and Habitat Survey by the Canadian Wildlife Service and United States Fish and Wildlife Service (USFWS) (Smith 1995). These waterfowl surveys are divided into more than 50 strata delineated according to habitat differences and political boundaries (URL:

http://www.fws.gov/birddata/databases/mas/aboutmas. htm). My study areas are contained in stratum 28, Prairie Alberta (URL:

http://mbirdims.fws.gov/nbii/). Data from 1955 to 2005 are available at the USFWS/United States Geological Survey website (URL:

http://www.fws.gov/birddata/databases/mas/maydb. html). Pond counts from stratum 28 from the years of this study (1995-2000) were compared with all other years, to determine whether this study was carried out in a series of average or "abnormal" water years.

\section{Statistical Analyses}

The relationship between number of birds seen during surveys and number of nests located was examined using a Pearson correlation (1-tailed test). Wetland type (managed, natural, or no basin), survey period (pre-incubation, early brood, late brood), and annual comparisons of godwit and willet survey numbers were conducted using a 3way ANOVA, Type III SS. All variables were logtransformed to improve normality. Non-significant interactions were sequentially deleted, beginning with the highest-order interactions. Dunnett's C was used to calculate post hoc multiple comparisons. Means are reported $\pm 1 \mathrm{SE}$. Because of the low numbers of long-billed curlews seen, logistic regression (Manly et al. 1993) was used to examine effects of wetland type, survey period, and year on presence of curlews. Nonparametric tests were used, as noted, when sample sizes were very low. All statistical tests were 2-tailed and considered significant at $P<0.05$ unless otherwise noted.

\section{RESULTS}

\section{Comparative Wetland Conditions}

Strata 28 spring pond counts from 1995 to 2000 were not significantly different from all other years (1995-2000 $n=6$, mean 88178, SD 38046, median 66750 , min $58766 \max 143245 ; 1955-2005$ excluding 1995-2000 $n=45$, mean 89607, SD 41889, median 77390, min 42892 max 215824; $t$ test 0.79 df 49 P 0.937; Mann Whitney U test P 0.809 ). The proportion of very wet years (Pond Counts >140 000) was also similar (1995-2000 $17 \%$; all other years $13 \%$ ).

\section{Abundance and Nest Densities in Different Basin Types}

From 1995 to 2000, both marbled godwits and willets were more often seen in areas with managed wetlands than in areas with natural or no wetland basins (Table 2, Appendix 1). Year effects and wetland type-year interactions are more difficult to understand, but may have been because numbers of both species were high in the wet summer of 1997 , especially in natural wetland basins. Numbers of both species were generally lower during the last (late brood) survey, as parents deserted the area after chicks died or fledged, resulting in a significant survey effect.

Numbers of willet nests (Table 3) tended to be highest in managed wetland basin areas each year, but results were variable and the difference was statistically significant in only one of 3 years (Kruskal-Wallis, 1-tailed test, $P=0.04$ in 1999). Results were similar for godwits (Kruskal-Wallis, 1 -tailed test, $P=0.02$ in 2000).

Logistic regression was used to simultaneously evaluate whether presence of curlews was related 
Table 2. Results of a 3-way ANOVA, type III SS, for marbled godwits and willets, based on log-transformed shorebird numbers. For both species, Dunnett $\mathrm{C}$ post hoc tests comparing wetland type were all significant $(P<0.05)$.

\begin{tabular}{llrrrr}
\hline \hline & Variable & SS & df & F & P \\
\hline wetland type & 15.1 & 2 & 105.4 & $<0.001$ \\
year & 1.9 & 5 & 5.4 & $<0.001$ \\
Marbled & survey period & 1.3 & 2 & 9.2 & $<0.001$ \\
Godwit & wetland*year & 1.4 & 10 & 1.9 & 0.035 \\
& wetland*survey & 0.4 & 4 & 1.3 & 0.254 \\
& year*survey & 0.6 & 10 & 0.9 & 0.524 \\
& wetland type & & & & $<0.001$ \\
& year & 28.8 & 2 & 246.5 & 0.046 \\
Willet & survey period & 0.7 & 5 & 2.3 & 0.026 \\
& wetland*year & 0.4 & 2 & 3.7 & $<0.001$ \\
& wetland*survey & 1.9 & 10 & 3.3 & 0.328 \\
& year*survey & 0.3 & 4 & 1.2 & 0.109 \\
\hline
\end{tabular}

to wetland type, year, and time of survey during the breeding season $(n=363)$. When the model was used to examine main effects only, the probability of sighting a curlew was related to time of survey $\left(\chi^{2}=16.47, \mathrm{df}=2, P \leq 0.001\right)$. Thirty-nine curlews were observed during pre-incubation, ten during early brooding, and nine during late brooding. Although not statistically significant in this analysis $\left(\chi^{2}=5.41, P=0.07\right)$, most sightings of curlews were in areas of natural wetland basins (32), compared with managed wetlands (15) and no wetland basins (11). In fact, ten of the 15 sightings in managed wetland areas were at Circle E, an area that had been a series of natural wetland basins until 1997. At Circle E, numbers of observed curlews averaged 1.4 birds during pre-management surveys (1995-1996) and 1.0 afterward (1997-2000); godwits 2.3 to 3.0; and willets 0.0 to 3.8. Only four curlew nests were found during this study, including one found during a survey in 1997, not a nest search. All curlew nests found were in areas of natural wetland basins.

\section{Survey Accuracy}

To determine whether survey results accurately reflect the number of nesting shorebirds in an area, numbers of nests found was compared with number of shorebirds seen during each survey at a site (Table 4). The relationship was more likely to be significantly positive for godwits than willets, and was the strongest during pre-incubation for both species in 1998 and 2000. Overall, 1.5 pairs of willets were seen during pre-incubation surveys for each nest later found at managed sites, but only 0.2 pairs per nest at unmanaged sites, suggesting that surveys overestimated breeding willets at sites with water, and underestimated them in dry areas. At both managed and unmanaged sites, 0.6 pairs of godwits were seen during pre-incubation for every nest later found. There were too few curlew nests for analysis.

At different periods of the breeding season, the number of marked birds observed during a survey was compared to the number known to have been 
Table 3. Mean number of marbled godwit, western willet, and long-billed curlew nests (+ SE) found in a single nest search of a 2-km² area in each of 9-10 survey routes from 1998 to 2000 in southeastern Alberta, where $n=$ number of areas nest searched.

\begin{tabular}{lllllllc}
\hline \hline Species & Year & $n$ & Managed & $n$ & Natural & $n$ & No basins \\
\hline \multirow{4}{*}{ Marbled godwit } & 1998 & 4 & $2.5(0.3)$ & 2 & $0(0)$ & 3 & $0(0)$ \\
& 1999 & 4 & $2.5(0.6)$ & 3 & $0.7(0.7)$ & 3 & $0.3(0.3)$ \\
& 2000 & 4 & $2.2(0.5)$ & 3 & $1.0(0.6)$ & 3 & $0(0)$ \\
Western willet & 1999 & 4 & $3.0(0.9)$ & 2 & $2.0(2.0)$ & 3 & $0(0)$ \\
& 2000 & 4 & $2.2(1.1)$ & 3 & $1.7(0.9)$ & 3 & $0.7(0.3)$ \\
& 1998 & $4.0(1.9)$ & 3 & $2.0(1.2)$ & 3 & $1.3(0.7)$ \\
Long-billed & 1999 & 4 & $0(0)$ & 2 & $0.5(0.5)$ & 3 & $0(0)$ \\
curlew & 2000 & 4 & $0(0)$ & 3 & $0.3(0.3)$ & 3 & $0(0)$ \\
& & 4 & $0(0)$ & 3 & $0.3(0.3)$ & 3 & $0(0)$ \\
\hline
\end{tabular}

in that area at the time of the survey. Considerably fewer birds with active nests were seen, compared with pre-laying birds or those with broods (Figure 2 ). During capture attempts, godwits flushed a median distance of $1 \mathrm{~m}$ from the nest $(n=25$ individuals, median $1 \mathrm{~m}$, range $<1$ to $2 \mathrm{~m}$ ), and willets $4 \mathrm{~m}(n=29$, range $<1$ to $50 \mathrm{~m} ; 17 / 29$ were within $5 \mathrm{~m}$ ). The non-incubating member of the pair was rarely seen before its mate was flushed (godwits $1 / 19$; willets $24 / 28$ ), and often was not sighted at all (godwits 11/19; willets 1/28).

\section{Nesting Success}

All but one failure at these nests appeared to be caused by predation of eggs or an incubating adult (after which the remaining adult deserted the clutch). Although sample sizes were small, Mayfield nest success was very similar among managed, natural, and no wetland sites (Figure 3). Nest success was consistently higher in 1999 than 1998 or 2000. Predation of incubating adults was rare, except in 2000, when both willet and godwit adults were found dead near nests in four widely separated survey areas (one godwit in each of a managed and natural wetland basin site; one willet in each of a different managed and natural wetland basin site).

\section{DISCUSSION}

\section{Survey Site Census and Nest Drag}

Both the surveys and nest searches indicated that nesting and foraging willets and godwits were more common in areas of managed wetlands, presumably because in most years in this region, virtually the only wetlands containing water by mid-May were managed. Willets, and to a lesser extent, godwits, increased in number at the four sites that had water in 1997 but were dry in previous years. Overall, willet and godwit numbers at sites with natural wetlands were not as high as those at managed wetlands in 1997, because not all natural basins were full and the percentage of water was lower than at managed sites (Table 1). Surprisingly, willets, normally considered more tied to water than marbled godwits (Godfrey 1986), and seldom seen in areas without water, were more often found nesting in drier areas than godwits. Long-billed curlews tended to be seen more often in areas with 
Table 4. Pearson correlation coefficients between western willets and marbled godwits seen during surveys, and nests found in the same areas, 1998-2000, in southeastern Alberta. For all survey periods, the number of sites where birds and nests were compared was four managed, three natural, three no wetland basin sites in 1999 and 2000, and four managed, two natural, and three no wetland basin sites in 1998.

\begin{tabular}{|c|c|c|c|c|c|c|}
\hline \multirow[t]{2}{*}{ Period } & \multicolumn{2}{|c|}{1998} & \multicolumn{2}{|c|}{1999} & \multicolumn{2}{|c|}{2000} \\
\hline & Willet & Godwit & Willet & Godwit & Willet & Godwit \\
\hline Pre-incubation & $0.89 * * *$ & $0.91 * * *$ & 0.40 & 0.34 & 0.55 & $0.91 * * *$ \\
\hline Early brood & $0.66^{*}$ & 0.50 & 0.20 & $0.56^{*}$ & 0.33 & $0.70^{*}$ \\
\hline Late brood & 0.45 & $0.87 * *$ & 0.40 & $0.54 *$ & 0.22 & 0.52 \\
\hline
\end{tabular}

Pearson product-moment correlations (one-tailed) were based on log-transformed data.

$*, * *, * * * P=0.05,0.01, \leq 0.001$, respectively.

natural wetland basins, and all curlew nests found during this study were at such sites. Given that longbilled curlews are a "species of special concern" in Canada, it might be useful to determine whether curlews tend to avoid managed wetlands in this region, and if so, why.

Even if managed wetlands attract more nesting shorebirds, it is possible that production is not as high in these areas as at natural wetland basin sites. Wetlands may attract large numbers of avian and mammalian predators in response to increased numbers of ground-nesting birds (especially waterfowl). This might be particularly important in areas with managed wetlands, where nesting densities are consistently high, as nest success is often inversely related to nest density in groundnesting birds (Clark and Nudds 1991). However, this did not appear to be the case here. Nest numbers in unmanaged sites were small, but overall there was no difference in nest success between areas with and without managed wetlands, and nest success appeared more related to year than wetland type. Brood survival was not examined, but was not likely higher in unmanaged than in managed wetland sites, as the parents normally took their chicks to the nearest shallow wetland. This was normally more than $2 \mathrm{~km}$ away (up to $12 \mathrm{~km}$ ) in unmanaged areas (compared with an average of $200 \mathrm{~m}$ in managed sites; pers. obs.).

Under climate change scenarios, temperatures are expected to increase in southern Alberta, resulting in a decrease in soil moisture and surface water
(Herrington et al. 1997, Oliver and Wiebe 2003, Barrow and $\mathrm{Yu}$ 2005). Wildlife species tied to semipermanent or ephemeral wetlands, such as those naturally used by willets, marbled godwits and longbilled curlews, are expected to be most affected in this region (Barrow and Lee 2000). This is likely to lead to their increased dependence on shallow managed wetlands. In addition, mountain runoff, which provides most of the irrigation, hydroelectric, and urban water in southern Alberta, is expected to decrease because of changes in snow accumulation and loss of glaciers (Oliver and Wiebe 2003). In this region in the future, higher temperatures and decreases in soil moisture are expected to result in an increased dependence on irrigated, rather than dry land crops. With decreased surface water and mountain runoff, and increased irrigation, competition among water users such as farmers, hydroelectric power generators, urban humans, livestock, and wildlife will become more intense. Grazing uses less water than irrigated cropland (Barrow and Lee 2003, Barrow and Yu 2005). If grazing increases at the expense of irrigated crops in southern Alberta, more shallow wetland basins are likely to be under water management, which may benefit willets and godwits under a drier climate regime.

\section{Accuracy of Survey Techniques}

According to the nest searches carried out in survey areas of this study, pre-incubation ATV surveys (early to mid-May) are a better measure of relative 
Fig. 2. Percentage of marked birds of specific breeding stages known to have been present in the survey area (Kitsim, $10 \mathrm{~km}$ east of Brooks, Alberta), that were observed during the survey. Data from willets and marbled godwits combined, and data from 1995 to 1998. Small numbers above bars refer to the fraction of birds seen of all available in that category. "Prelay" refers to the total number of marked birds that later (within $2 \mathrm{wk}$ ) incubated a nest in the survey route area; "Incub" refers to the total number of marked birds known to have an active nest in the survey route area; "failed" is the total number of marked birds with recently failed nests, whose nests had been in the survey route area; "brood" is the total number of marked adults attending broods that had been seen in the survey route area within $3 \mathrm{~d}$ of a survey date (by independent brood surveys).

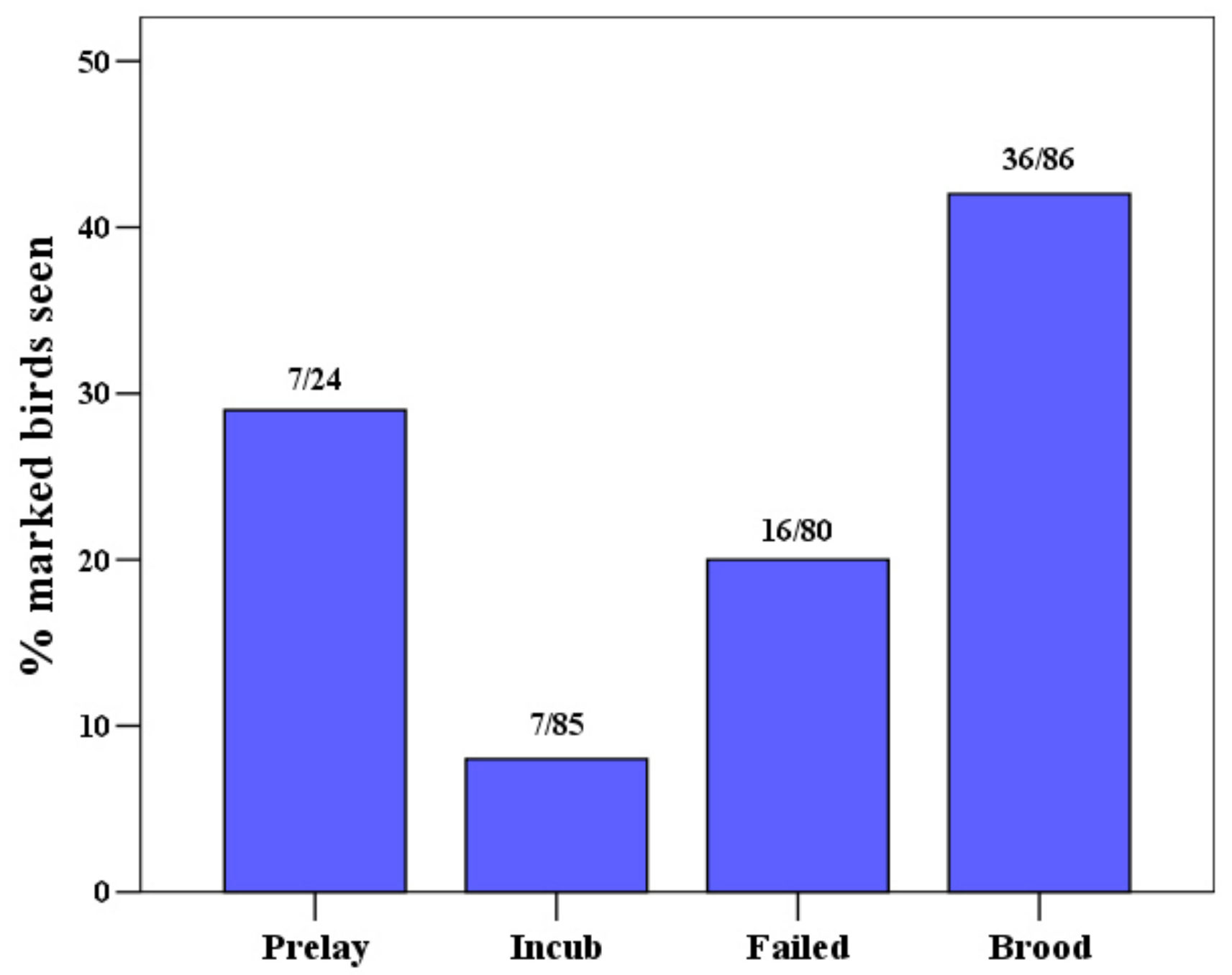


Fig. 3. Shorebird (marbled godwits, willets, and long-billed curlews combined) Mayfield nest success in survey areas with managed, natural, and no wetland basins from 1998 to 2000 in southeastern Alberta. Numbers above bars refer to the fraction of nests hatched of the total nests found. Sample sizes are too small for statistical analysis (the $95 \%$ confidence intervals on the Mayfield estimates were as follows: managed, 1998-2000: 5-44\%, 13-70\%, 3-30\%; natural, 1998-2000: 1-100\%, 7-97\%, 2-74\%; no basin, 1999-2000: 4-100\%, 1-100\%).

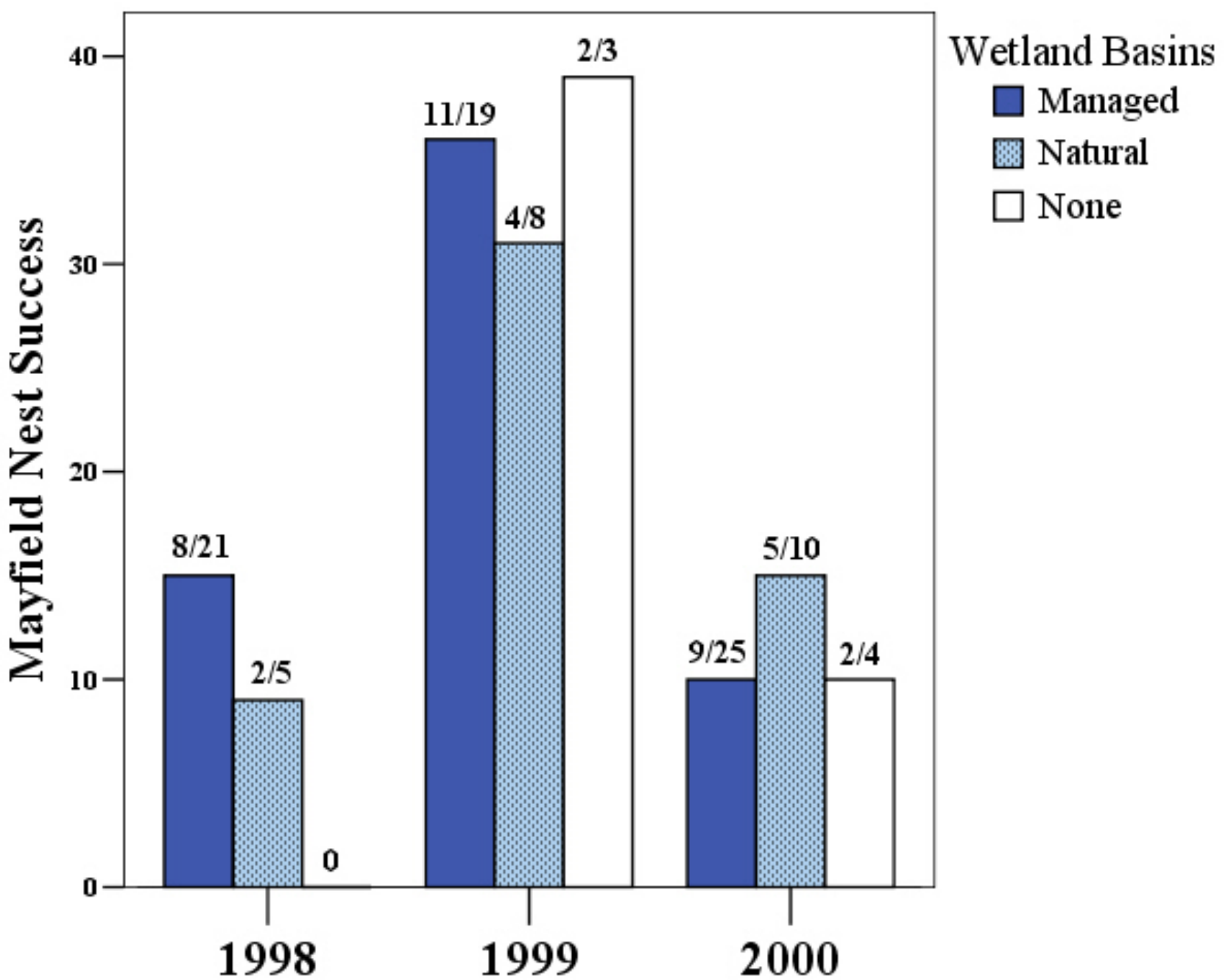

numbers of upland breeding shorebirds than surveys carried out later in the breeding period (Table 4). Even then, surveys overestimated numbers of willets breeding in managed wetland areas, and underestimated numbers of willets breeding in areas without water. Presumably this is because most shorebirds seen during surveys are foraging, Willets almost always forage in areas with water, and water was normally only found where wetlands were managed in most of the years of this study. Brood surveys around wetlands appear to accurately indicate, by behavior of attending parents, numbers of broods present, but they give no indication of how far the birds have moved from their nest sites. It 
seems unlikely that specific broad-scale breeding surveys will be carried out for marbled godwits and willets, but they are likely to be included in surveys of other species, such as the COSEWIC-listed longbilled curlew. If so, it is important to consider, in study design and interpretation of results, the behavior of the species at the time of year the surveys are carried out. Timing of breeding differs among upland-nesting shorebirds in a region, with longbilled curlews nesting on average almost a week earlier than godwits, 10 d earlier than willets, and 3 wk earlier than upland sandpipers (Bartramia longicauda; C. L. Gratto-Trevor, unpublished data; Jackson 2003).

The only current monitoring scheme for marbled godwits and western willets is the Breeding Bird Survey (BBS; Robbins et al. 1986), which uses timed roadside point counts and identification of most species by sound, and is normally carried out in early to late June. This corresponds to the incubation and early brood periods for these two species. As shown by this study, surveys for willets and marbled godwits carried out during the incubation period (mid-May to early June) do not accurately measure nesting density. Less than $10 \%$ of the marked birds with current nests in the survey area were seen (or heard) during specific ATV surveys. The behavior of these birds changes dramatically at hatch, with adults actively and vociferously defending young, which they normally guide to the nearest appropriate wetland (shallow water, emergent vegetation but not cattail cover; Gratto-Trevor et al. 2000, Lowther et al. 2001). If BBSs are carried out during the incubation period, marbled godwits and willets will only be seen if shallow wetlands are present, and they are unlikely to be heard as they are seldom vocal at this time. As noted, after their eggs hatch, adults will be much more visible and vocal. However, their presence will depend not only on availability of suitable brood wetlands, but on nest and brood success in a given year, and timing of survey vs. hatch in that year. If a survey route encompasses a suitable permanent wetland (or even a field being irrigated at that time), numbers could be largest in years where nest failure is high, and birds congregate early at the few suitable sites remaining. All this would add variability to survey numbers, which would make any real population trends in these species difficult to determine by the current BBS. Whether numbers of BBS (or Grassland Bird Survey; B. Dale pers. comm.) routes through native prairie can be increased sufficiently to adequately monitor populations of upland nesting shorebirds has yet to be determined.

Responses to this article can be read online at: http://www.ace-eco.org/voll/iss2/art2/responses/

\section{Acknowledgments:}

This project received funding from the Canadian Wildlife Service (Environment Canada, Prairie and Northern Region), and the Alberta North American Waterfowl Management Plan Centre (Biodiversity Fund). Ducks Unlimited Canada (Alberta) provided logistical support, especially T. Sadler and the Brooks office. The Eastern Irrigation District gave permission to work on their lands, as did the Antelope Creek, Circle E, and Loman Grazing Associations. Field assistance was primarily provided by D. Pearson, H. Johnston, $S$. vanWilgenburg, G. Perrin, A. Keeley, G. Thibault, and A. Neudorf. K. Guyn's pintail crew found most of the shorebird nests at Kitsim in the first 3 years of this study. S. Rangen assisted with data analysis, and S. vanWilgenburg with data input. Comments from $M$. Hill and K. Mehl greatly improved the manuscript, as did comments from ACE editors and several anonymous reviewers.

\section{LITERATURE CITED}

Allen, J. N. 1980. The ecology and behavior of the long-billed curlew in southeast Washington. Wildlife Monographs 73.

Anderson, D. R., and F. A. Glover. 1967. Effects of water manipulation on waterfowl production and habitat. Transactions of the North American Wildlife and Natural Resources Conference 32:292-300.

Barrow, E. M., and R. J. Lee. 2000. Climate change and environmental assessment. Part 2. Climate change guidance for environmental assessment. Research and Development Monograph Series, Canadian Environmental Assessment Agency, Ottawa, Ontario, Canada. (Online.) URL: http://www.ceaa-acee.gc.ca/015/0002/0004/index e. htm. 
Barrow, E. M., and G. Yu. 2005. Climate scenarios for Alberta. A report prepared for the Prairie Adaptation Research Collaborative (PARC) in cooperation with Alberta Environment. (Online.) URL:

http://www.parc.ca/pdf/Alberta Scenarios/main report. pdf

Clark, J. S., E. C. Grimm, J. J. Donovan, S. C. Fritz, D. R. Engstrom, and J. E. Almendinger. 2002. Drought cycles and landscape responses to past aridity on prairies of the northern Great Plains, USA. Ecology 83:595-601.

Clark, R. C., and T. D. Nudds. 1991. Habitat patch size and duck nesting success: the crucial experiments have not been performed. Wildlife Society Bulletin 19:534-543.

Colwell, M. A., and O. W. Taft. 2000. Waterbird communities in managed wetlands varying in water depth. Waterbirds 23:45-55.

Dahl, T. E. 1990. Status of prairie pothole wetlands in the United States. U.S. Fish and Wildlife Service, National Wetland Inventory, St. Petersburg, Delaware, USA.

Delphey, P. J., and J. J. Dinsmore. 1993. Breeding bird communities of recently restored and natural prairie potholes. Wetlands 13:200-206.

Diamond, A. W., and R. K. Brace. 1991. Climate and waterfowl populations. Pages 245-257 in G. Wall, editor. Symposium on the impacts of climatic change and variability on the Great Plains, September 1990. Department of Geography Publication Series, Occasional Paper No. 12. University of Waterloo, Waterloo, Ontario, Canada.

Dugger, B. D., and K. M. Dugger. 2002. Longbilled Curlew (Numenius americanus). Volume 628 in A. Poole and F. Gill, editors. The birds of North America. The Birds of North America, Inc., Philadelphia, Pennsylvania, USA.

Fairbairn, S. E., and J. J. Dinsmore. 2001 . Factors associated with occurrence and density of wetland birds in the prairie pothole region of Iowa. Journal of the Iowa Academy of Science 108:8-14.

Godfrey, W.E. 1986. The birds of Canada. Revised edition. National Museum of Natural Sciences, National Museums of Canada, Ottawa, Ontario, Canada.

Gratto-Trevor, C. L. 2000. Marbled Godwit (Limosa fedoa). Volume 492 in A. Poole and F. Gill, editors. The birds of North America. The Birds of North America, Inc., Philadelphia, Pennsylvania, USA.

Gratto-Trevor, C. L. 2004. The North American Bander's manual for shorebirds. North American Banding Council Publication Committee, Point Reyes Station, California, USA.

Gratto-Trevor, C. L., G. Beyersbergen, H. L. Dickson, P. Erickson, R. MacFarlane, M. Raillard, and T. Sadler. 2001. Prairie Canada shorebird conservation plan. Prairie Habitat Joint Venture and Canadian Wildlife Service, Edmonton, Alberta, Canada.

Gratto-Trevor, C. L., V. H. Johnston, and S. T. Pepper. 1998. Changes in shorebird and eider abundance in the Rasmussen Lowlands, NWT. Wilson Bulletin 110:316-325.

Hays, H., and M. LeCroy. 1971. Field criteria for determining incubation stage in eggs of the Common Tern. Wilson Bulletin 83:425-429.

Hazler, K. 2004. Mayfield logistic regression: a practical approach for analysis of nest survival. Auk 121:707-716.

Herrington, R., B. Johnson, and F. Hunter. 1997. Responding to global climate change in the prairies. Volume III of the Canada country study: climate impacts and adaptation. Environment Canada, Ottawa, Ontario, Canada.

Higgins, K. F., L. M. Kirsch, H. F. Duebbert, A. T. Klett, J. T. Lokemoen, W. H. Miller, and A. D. Kruse. 1977. Construction and operation of cablechain drag for nest searches. U.S. Fish and Wildlife Service, Wildlife Leaflet 512. Washington, D.C., USA.

Higgins, K. F., L. M. Kirsch, M. R. Ryan, and R. B. Renken. 1979. Some ecological aspects of marbled godwits and willets in North Dakota. Prairie Naturalist 11:115-118.

Howe, M. A. 1982a. Breeding ecology of North 
American shorebirds: patterns and constraints. Pages 95-100 in Symposium on Waterfowl and Waders. Washington, D.C., USA.

Howe, M.A. 1982b. Social organization in a nesting population of Eastern Willets (Catoptrophorus semipalmatus). Auk 99:88-102.

Howe, M.A., P. H. Geissler, and B.A. Harrington. 1989. Population trends of North American shorebirds based on the International Shorebird Survey. Biological Conservation 49:185-199.

Jackson, C. 2003. Breeding ecology of prairie nesting shorebirds: relationships with habitat, land use and predators. Thesis, University of Saskatchewan, Saskatoon, Saskatchewan, Canada.

Jehle, G., A. A. Yackel Adams, J. A. Savidge, and S. K. Skagen. 2004. Nest survival estimates: a review of alternatives to the Mayfield estimator. Condor 106:472-484.

Johnson, D. H. 1979. Estimating nest success: the Mayfield method and an alternative. Auk 96:651661.

Kantrud, H. A., and R. E. Stewart. 1984. Ecological distribution and crude density of breeding birds on prairie wetlands. Journal of Wildlife Management 48:426-437.

Klett, A. T., H. A. Duebbert, C. A. Faanes, and K. F. Higgins. 1986. Techniques for studying nest success of ducks in upland habitats in the prairie pothole region. U.S. Department of the Interior, Fish and Wildlife Service Resource Publication 158. Washington, D.C., USA.

Lowther, P. E., H. D. Douglas, III, and C. L. Gratto-Trevor. 2001. Willet (Catoptrophorus semipalmatus). Volume 579 in A. Poole and F. Gill, editors. The birds of North America. The Birds of North America, Inc., Philadelphia, Pennsylvania, USA.

Manly, B., L. McDonald, and D. Thomas. 1993. Resource selection by animals: statistical design and analysis for field studies. Chapman and Hall, London, UK.

Manolis, J. C., D. E. Anderson, and F. J. Cuthbert. 2000. Uncertain nest fates in songbird studies and variation in Mayfield estimation. Auk
117:615-626.

Mayfield, H. 1961. Nesting success calculated from exposure. Wilson Bulletin 73:255-261.

Mayfield, H. 1975. Suggestions for calculating nest success. Wilson Bulletin 87:456-466.

Morrison, R. I. G., Y. Aubry, R. W. Butler, G. W. Beyersbergen, G. M. Donaldson, C. L. GrattoTrevor, P. W. Hicklin, V. H. Johnston, and R. K. Ross. 2001. Declines in North American shorebird populations. Wader Study Group Bulletin 94:34-38.

Morrison, R. I. G., C. Downes, and B. Collins. 1994. Population trends of shorebirds on fall migration in eastern Canada. Wilson Bulletin 106:431-447.

Nur, N., A. L. Holmes, and G. R. Geupel. 2004. Use of survival time analysis to analyze nesting success in birds: an example using Loggerhead Shrikes. Condor 106:457-471.

Oliver, D., and J. Wiebe, editors. 2003. Climate change: we are at risk. Final report to the Standing Senate Committee on Agriculture and Forestry, Canadian Parliament, Ottawa, Ontario, Canada. (Online.) URL:

http://www.parl.gc.ca/37/2/parlbus/commbus/senate/ com-e/AGRI-E/23app-e.pdf.

Page, G. W., and R. E. Gill, Jr. 1994. Shorebirds in western North America: late 1800s to late 1900s. Studies in Avian Biology 15:147-160.

Redmond, R. L., and D. A. Jenni. 1986. Population ecology of the Long-billed Curlew (Numenius americanus) in western Idaho. Auk 103:755-767.

Robbins, C. S., D. Bystrak, and P. H. Geissler. 1986. The Breeding Bird Survey: its first fifteen years, 1965-1979. U.S. Fish and Wildlife Service Resource Publication No. 157, Washington, D.C., USA.

Ruwaldt, J. J., Jr., L. D. Flake, and J. M. Gates. 1979. Waterfowl pair use of natural and man-made wetlands in South Dakota. Journal of Wildlife Management 43:375-383.

Ryan, M. R., and R. B. Renken. 1987. Habitat use by breeding Willets in the Northern Great Plains. Wilson Bulletin 99:175-189. 
Ryan, M. R., R. B. Renken, and J. J. Dinsmore. 1984. Marbled godwit habitat selection in the Northern Prairie Region. Journal of Wildlife Management 48:1206-1218.

Salt, W. R., and J. R. Salt. 1976. The birds of Alberta. Hurtig Publishers, Edmonton, Alberta, Canada.

Saunders, E. J. 2002. Update status report on longbilled curlew, Numenius americanus. Committee on the Status of Endangered Wildlife in Canada, COSEWIC Secretariat, Canadian Wildlife Service, Environment Canada, Ottawa, Ontario, Canada.

Shaffer, Y. 2004. A unified approach to analyzing nest success. Auk 121:526-540.

Smith, G. W. 1995. A critical review of the aerial and ground surveys of breeding waterfowl in North America. Biological Science Report 5. National Biological Service, Washington, D.C., USA.

Environment Canada. 1991. The state of Canada's environment. Environment Canada, Ottawa, Ontario, Canada.

Sordahl, T. A. 1979. Vocalizations and behavior of the Willet. Wilson Bulletin 91:551-574.

Sorenson, L. G., R. Goldberg, T. L. Root, and M. G. Anderson. 1998. Potential effects of global warming on waterfowl populations breeding in the northern Great Plains. Climatic Change 40:343369.

Twedt, D. J., C. O. Nelms, V. E. Rettig, and S. R. Aycock. 1998. Shorebird use of managed wetlands in the Mississippi Alluvial Valley. American Midland Naturalist 140:140-152.

Weber, L., and S. M. Haig. 1996. Shorebird use of South Carolina managed and natural coastal wetlands. Journal of Wildlife Management 60:7382 . 
APPENDIX 1. Mean number of marbled godwits, western willets, and long-billed curlews seen on survey routes (+ SE) during pre-incubation (Preinc), early brood (E brood), and late brood (L brood) periods from 1995 to 2000 in areas of managed, natural, and no wetland basins in southeastern Alberta.

\begin{tabular}{|c|c|c|c|c|c|c|c|c|c|c|c|c|}
\hline \multicolumn{5}{|c|}{ Managed wetland basins } & \multicolumn{4}{|c|}{ Natural wetland basins } & \multicolumn{3}{|c|}{ No wetland basins } & \multirow[b]{2}{*}{ L brood } \\
\hline Year & $n$ & Preinc & E brood & L brood & $n$ & Preinc & E brood & L brood & $n$ & Preinc & E brood & \\
\hline \multicolumn{13}{|c|}{ Marbled Godwit } \\
\hline 1995 & 7 & $2.6(0.5)$ & $6.0(1.0)$ & $5.3(1.7)$ & 5 & $0(0)$ & $1.0(1.0)$ & $0.4(0.4)$ & 4 & $1.0(0.4)$ & $0.8(0.5)$ & $0.5(0.5)$ \\
\hline 1996 & 8 & $4.1(1.3)$ & $5.9(1.9)$ & $2.5(1.3)$ & 8 & $2.4(0.7)$ & $1.8(0.9)$ & $0.6(0.3)$ & 5 & $0.8(0.5)$ & $0.2(0.2)$ & $0(0)$ \\
\hline 1997 & 9 & $4.0(1.2)$ & $5.6(1.7)$ & $5.9(2.2)$ & 7 & $3.1(0.9)$ & $1.7(0.7)$ & $1.4(0.7)$ & 5 & $0.4(0.2)$ & $0.8(0.8)$ & $0.2(0.2)$ \\
\hline 1998 & 9 & $4.0(0.6)$ & $1.4(0.5)$ & $0.6(0.2)$ & 7 & $0.3(0.3)$ & $0.6(0.3)$ & $0.1(0.1)$ & 5 & $0.2(0.2)$ & $0(0)$ & $0(0)$ \\
\hline 1999 & 9 & $3.0(1.0)$ & $4.2(1.1)$ & $1.3(0.4)$ & 7 & $1.4(0.5)$ & $1.7(1.1)$ & $0.3(0.3)$ & 5 & $0(0)$ & $0.6(0.6)$ & $0.2(0.2)$ \\
\hline 2000 & 9 & $5.3(1.7)$ & $5.2(1.2)$ & $1.9(1.0)$ & 7 & $0.7(0.3)$ & $0.3(0.3)$ & $0(0)$ & 5 & $0.2(0.2)$ & $0(0)$ & $0(0)$ \\
\hline \multicolumn{13}{|c|}{$\begin{array}{l}\text { Western W- } \\
\text { illet }\end{array}$} \\
\hline 1995 & 7 & $3.0(0.7)$ & $5.0(1.4)$ & $6.7(0.6)$ & 5 & $0(0)$ & $0(0)$ & $0(0)$ & 4 & $0(0)$ & $0.2(0.2)$ & $0.5(0.5)$ \\
\hline 1996 & 8 & $5.9(1.0)$ & $8.9(2.9)$ & $5.1(1.7)$ & 8 & $1.2(0.7)$ & $0.8(0.6)$ & $0.1(0.1)$ & 5 & $0(0)$ & $0(0)$ & $0(0)$ \\
\hline 1997 & 9 & $4.4(0.8)$ & $4.1(1.0)$ & $3.7(1.1)$ & 7 & $2.6(1.0)$ & $0.7(0.5)$ & $2.3(1.2)$ & 5 & $0.6(0.4)$ & $0.8(0.8)$ & $1.0(1.0)$ \\
\hline 1998 & 9 & $7.0(1.4)$ & $2.9(0.6)$ & $1.6(0.5)$ & 7 & $0.9(0.3)$ & $0.3(0.3)$ & $0.1(0.1)$ & 5 & $0.2(0.2)$ & $0(0)$ & $0(0)$ \\
\hline 1999 & 9 & $4.9(1.1)$ & $4.2(1.1)$ & $2.3(0.8)$ & 7 & $0.9(0.6)$ & $0.4(0.2)$ & $0.1(0.1)$ & 5 & $0.4(0.4)$ & $0.8(0.5)$ & $0.2(0.2)$ \\
\hline 2000 & 9 & $8.2(2.3)$ & $4.9(1.2)$ & $4.1(0.6)$ & 7 & $0.6(0.4)$ & $0.1(0.1)$ & $0(0)$ & 5 & $0(0)$ & $0(0)$ & $0(0)$ \\
\hline \multicolumn{13}{|c|}{ Long-billed Curlew } \\
\hline 1995 & 7 & $0(0)$ & $0(0)$ & $0(0)$ & 5 & $0(0)$ & $0.4(0.4)$ & $0.8(0.6)$ & 4 & $0.2(0.2)$ & $0(0)$ & $0.8(0.5)$ \\
\hline 1996 & 8 & $0(0)$ & $0(0)$ & $0.1(0.1)$ & 8 & $1.5(0.6)$ & $0.4(0.3)$ & $0.1(0.1)$ & 5 & $0(0)$ & $0(0)$ & $0(0)$ \\
\hline 1997 & 9 & $0.6(0.4)$ & $0.2(0.2)$ & $0(0)$ & 7 & $0(0)$ & $0(0)$ & $0(0)$ & 5 & $0.4(0.4)$ & $0(0)$ & $0(0)$ \\
\hline 1998 & 9 & $0.3(0.2)$ & $0(0)$ & $0(0)$ & 7 & $0.7(0.4)$ & $0(0)$ & $0(0)$ & 5 & $0.2(0.2)$ & $0(0)$ & $0(0)$ \\
\hline 1999 & 9 & $0.2(0.2)$ & $0.1(0.1)$ & $0(0)$ & 7 & $0.3(0.2)$ & $0.3(0.3)$ & $0(0)$ & 5 & $0.4(0.4)$ & $0(0)$ & $0(0)$ \\
\hline 2000 & 9 & $0.1(0.1)$ & $0(0)$ & $0(0)$ & 7 & $0.1(0.1)$ & $0(0)$ & $0(0)$ & 5 & $0.4(0.4)$ & $0(0)$ & $0(0)$ \\
\hline
\end{tabular}

